\title{
The Effects of Dietary Olive Cake Meal on Fattening Performance, Carcass and Slaughter Traits in Japanese Quails (Coturnix coturnix japonica)
}

\author{
Cahit Özcan ${ }^{1, a}$, Tülay Çimrin ${ }^{2, b, *}$, Yasin Yakar ${ }^{3, c}$, Sema Alaşahan ${ }^{4, d}$ \\ ${ }^{1}$ Department of Animal Nutrition and Nutritional Diseases, Faculty of Veterinary Medicine, Siirt University, 56100 Siirt, Turkey \\ ${ }^{2}$ Department of Animal Science, Faculty of Agriculture, Hatay Mustafa Kemal University, 31034 Hatay, Turkey \\ ${ }^{3}$ Department of Food Engineering, Faculty of Engineering, Harran University, 63000 Şanlurfa, Turkey \\ ${ }^{4}$ Department of Animal Breeding, Faculty of Veterinary Medicine, Hatay Mustafa Kemal University, 31034 Hatay, Turkey \\ *Corresponding author
}

\section{A R T I C L E I N F O A B S T R A C T}

Research Article

This study was aimed at investigating the effects of dietary supplementation with different levels of olive cake meal $(0 \%, 2.5 \%, 5 \%$ and $7.5 \%)$ on the fattening performance and slaughter and carcass traits of quails. For this purpose, 400 one-day-old Japanese quail chicks were randomly assigned to 4 groups, each with 5 replicates. The quails were fed on either a basal diet alone (Control Group) or a basal diet supplemented with olive cake meal at rates of 2.5\% (Group I), 5\% (Group II) and $7.5 \%$ (Group III) for a period of 42 days. At the end of the fattening period, dietary olive cake meal was observed not to have caused any adverse effect on body weight, feed intake and feed conversion rate. Eviscerated hot carcass weight, eviscerated cold carcass weight, wing weight, breast weight, thigh weight and edible visceral organ weights were determined to have improved in the treatment groups that received dietary olive cake meal, when compared to the control group. In conclusion, dietary supplementation with olive cake meal, a waste product of the olive oil industry, at a level of $5 \%$, was observed to produce the closest and most similar results to those of feeding on the basal diet. Thus, it is suggested that olive cake meal could be used as an alternative feedstuff for poultry. Furthermore, the use of olive cake meal as an alternative feedstuff would contribute to reducing both feed costs and environmental pollution.

Alternative feedstuff

Growth traits

Olive oil by-product

Edible organ weights Waste product cahitozcan@siirt.edu.tr yasinyakar@harran.edu.tr
(iD) http://orcid.org/0000-0002-1047-5347 (iD) http://orcid.org/0000-0003-3297-3379 http://orcid.org/0000-0002-5868-4148 http://orcid.org/0000-0002-1144-7786

\section{Introduction}

Olive trees, which are classified under the family Oleaceae, are considered an important species. The major olive production sites in Turkey are the Aegean, Marmara, Mediterranean and Southeastern Anatolia regions. The number of olive trees within the territory of Turkey has steadily increased between 1988-2019 and has reached a total number of $182,076,000$. In 2019, the amount of table olives and olive oil produced from 154,037,000 fruitbearing olive trees were 415,000 tonnes and 1,110,000 tonnes, respectively.

Olive oil production results in two types of endproducts, which are fluid and solid wastes. Fluid wastes are referred to as black water or wash water. Solid waste resulting from the crushing of olives is referred to as pomace and is comprised of the pit, skin and pulp of olives. Olive processing generates approximately $35-45 \%$ of dry pomace. There are 3 types of pomaces with different water content. Pomace is of economic value and is generally used as a fuel. On the other hand, pomace is also reported to be used as a feedstuff for cattle and as a fertilizer for soil (Amici et al., 1991; Weinberg et al., 2008; Ghasemi et al., 2014). Thus, wet olive cake, generated as an end-product of olive oil production, once processed, serves as a favourable and valuable material for use in sustainable and/or organic animal production, given its natural origin and harmlessness to human health.

Olive cake meal contains a high level of cellulose as well as tannin and phenolic compounds. Olive cake meal is also known to be rich in essential fatty acids, including oleic acid, linoleic acid, palmitoleic acid and linolenic acid (El-Hachemi et al., 2007; Dalkilic, 2018). Reports have been published, which suggest that dietary supplementation with even small amounts of olive cake meal improves both production yields and product quality 
in milk- and meat-type cattle, sheep and goats (Chiofalo et al., 2004; Sadeghi et al., 2009; Özdoğan et al., 2017; Cibik et al., 2016; Dalk1lıc, 2018). Furthermore, several studies have been carried out to investigate the effects of olive oil industry by-products, namely olive leaves, black water and olive pomace on broiler chicken and laying hen performance (Zangeneh and Torki, 2011; Zarei et al., 2011; Ozdemir and Azman, 2013; Cayan and Erener, 2015; Tuzun and Unlu, 2016; Ibrahim et al., 2018).

This study was aimed at determining the effects of dietary supplementation with olive cake meal, an olive oil by-product, on the fattening performance of quails, and thereby, at investigating the possible use of olive cake meal as a feedstuff for poultry. In this context, the present study is expected to contribute to both reducing feed costs, which constitute three-quarters of poultry production expenses, and assessing alternative feedstuffs.

\section{Materials and Methods}

This study was approved by the Ethics Board for Scientific and Academic Research and Publications of Siirt University, and conducted pursuant to the 27/03/2019 dated and 2019/01 numbered decision of the Board. Fertilized eggs, supplied from the Application and Research Centre for Wildlife Conservation and Rehabilitation of Siirt University, constituted the study material. The fertilized eggs were placed in an incubator at the Centre from which they were supplied, and the hatching of chicks was achieved at the end of a 17-day-incubation period. Hatchling chicks were examined macroscopically, and those confirmed to have a healthy body structure were weighed individually to determine their hatching weight. These chicks were randomly assigned to the study groups.

\section{Study Groups and Feed Composition}

In this study, 400 one-day-old Japanese quail chicks (Coturnix coturnix japonica) were randomly assigned to 4 study groups, each with 5 replicates of 20 animals. A chick starter feed (basal diet) and olive cake meal (OCM) were used to feed the chicks (Table 2). The control group received the basal diet alone, whilst Groups I, II and III were fed on the basal diet supplemented with $2.5 \%, 5 \%$ and $7.5 \%$ of OCM, respectively. The quails were fed for a period of 42 days.

Feed was prepared on a weekly basis, and the animals were provided with ad libitum feed. Throughout the study period, the drinkers and feeders were checked twice a day, and were cleaned and replenished as required.

The diets were formulated to be isocaloric and isonitrogenous, according to nutritional values published by the National Research Council (NRC) (1994). Dry matter, crude ash, crude protein and crude fat analyses were performed according to the official analysis methods of the Association of Official Analytical Chemists (AOAC) (1990), whilst crude cellulose levels and metabolic energy ( $\mathrm{kcal} / \mathrm{kg}$ ) were determined as described by Crampton and Maynard (1983) and Larbier and Leclercq (1994), respectively (Table 1).

\section{Determination of Fattening Performance}

The weekly live weights of the animals were determined by individually weighing the quails each week on a precision balance accurate to $0.01 \mathrm{~g}$. Weightings were performed between weeks 0-6. The weightings performed in the third week were also categorized for sex (male, female). Sex determination was based on the breast plumage colouration of the quails. Quails with speckled breast feathers were identified as female, whilst quails with brown breast feathers were identified as male.

\section{Rates}

Determination of Feed Intake and Feed Conversion

The feed intake of each group was determined on a weekly basis. Weekly feed intake was calculated by subtracting the amount of feed remaining in the feeders from the amount of feed provided to the animals. The feed conversion rate was calculated by dividing the feed intake by the body weight gain.

\section{Determination of Slaughter Traits}

For the purpose of determining the slaughter traits, 30 females and 30 males were selected from each group, based on their mean live weights in week 6 . Accordingly, a total of $120(30 \times 4)$ females and $120(30 \times 4)$ males were slaughtered. The slaughter traits investigated in this study included the body weight at slaughter, eviscerated hot carcass weight, liver weight, heart weight and gizzard weight. After the whole carcass was stored at $+4^{\circ} \mathrm{C}$ for $24 \mathrm{~h}$, the eviscerated cold carcass weight was determined. The whole eviscerated cold carcasses were cut into four parts, including the thigh, wing, breast and back+neck. After these parts were cut, the thigh, breast, wing and back+neck weights were also determined.

Calculation of percentage values for the slaughter and carcass traits of the study groups:

$$
\text { Hot carcass yield }=\frac{\text { Hot carcass weight }(\mathrm{g})}{\text { Slaughter weight }(\mathrm{g})} \times 100
$$

Thigh percentage $(\%)=\frac{\text { Thigh weight }}{\text { Eviscerated cold carcass weight }} \times 100$

$$
\text { Breast percentage }(\%)=\frac{\text { Breast weight }}{\text { Eviscerated cold carcass weight }} \times 100
$$

$$
\text { Wing percentage }(\%)=\frac{\text { Wing weight }}{\text { Eviscerated cold carcass weight }} \times 100
$$

Back + neck percentage $(\%)=\frac{\text { Back }+ \text { neck weight }}{\text { Eviscerated cold carcass weight }} \times 100$

$$
\begin{aligned}
& \text { Liver percentage }(\%)=\frac{\text { Liver weight }}{\text { Slaughter weight }} \times 100 \\
& \text { Heart percentage }(\%)=\frac{\text { Heart weight }}{\text { Slaughter weight }} \times 100 \\
& \text { Gizzard percentage }(\%)=\frac{\text { Gizzard weight }}{\text { Slaughter weight }} \times 100
\end{aligned}
$$

\section{Statistical Analyses}

Data obtained from the study groups was analysed with the IBM SPSS Statistics 22 software package. Whether or not the mean values of the groups differed from each other was analysed with one-way analysis of variance (one-way ANOVA). Differences between the study groups were determined with Duncan's multiple range test. 
Table 1 . The composition and nutrient content $(\%)$ of the basal diet

\begin{tabular}{|c|c|c|c|}
\hline Feedstuffs & $\%$ & Feed Additives & $\%$ \\
\hline Maize & 49 & Methionine & 0.27 \\
\hline Soybean Meal & 33.4 & Salt & 0.16 \\
\hline Whole-fat Soybean & 4 & Sodium Sulphate & 0.11 \\
\hline Bonkalite & 4 & Mineral Premix & 0.01 \\
\hline Sunflower Seed Meal & 2.5 & Vitamin Premix & 0.01 \\
\hline Chicken Meal & 2.5 & Threonine & 0.07 \\
\hline Marble Powder & 1.45 & Toxin Binder & 0.1 \\
\hline Soybean Oil & 1.08 & Coccidiostat & 0.05 \\
\hline Monocalcium phosphate (MCP) & 0.7 & Choline Chloride & 0.07 \\
\hline Lysine Sulphate & 0.34 & & \\
\hline \multicolumn{4}{|c|}{ Nutrient Content Determined by Analysis } \\
\hline \multicolumn{2}{|l|}{ Dry Matter \% } & \multicolumn{2}{|c|}{91.28} \\
\hline \multicolumn{2}{|l|}{ Crude Ash \% } & \multicolumn{2}{|c|}{4.75} \\
\hline \multicolumn{2}{|l|}{ Crude Fat \% } & \multicolumn{2}{|c|}{5.39} \\
\hline \multicolumn{2}{|l|}{ Crude Protein \% } & \multicolumn{2}{|c|}{20.69} \\
\hline \multicolumn{2}{|l|}{ Crude Cellulose $\%$} & \multicolumn{2}{|c|}{3.33} \\
\hline \multicolumn{2}{|l|}{ Starch \% } & \multicolumn{2}{|c|}{35.65} \\
\hline \multicolumn{2}{|l|}{$\mathrm{Ca} \%$} & \multicolumn{2}{|c|}{0.77} \\
\hline \multicolumn{2}{|l|}{$\mathrm{P} \%$} & \multicolumn{2}{|c|}{0.48} \\
\hline \multicolumn{2}{|l|}{ Sugar $\%$} & \multicolumn{2}{|c|}{8.50} \\
\hline \multicolumn{2}{|l|}{ Metabolic Energy, $\mathrm{kcal} / \mathrm{kg}^{* *}$} & \multicolumn{2}{|c|}{2914.80} \\
\hline \multicolumn{4}{|c|}{$\begin{array}{l}1 \mathrm{~kg} \text { of the premix contained 15,000,000 IU of Vitamin A, 5,000,000 IU of Vitamin D3, 100,000 mg of Vitamin E, } 3000 \mathrm{mg} \text { of Vitamin K3,5000 mg } \\
\text { of Vitamin B1, } 8000 \mathrm{mg} \text { of Vitamin B2, 60,000 mg of niacin, 15,000 mg of D-calcium pantothenate, } 5000 \mathrm{mg} \text { of Vitamin B6, } 20 \mathrm{mg} \text { of Vitamin B12, } \\
200 \mathrm{mg} \text { of D-biotin, } 2000 \mathrm{mg} \text { of folic acid, and 100,000 } \mathrm{mg} \text { of Vitamin C. }\end{array}$} \\
\hline \multicolumn{4}{|c|}{ Table 2 . The analysis results of the olive cake meal supplement } \\
\hline \multicolumn{2}{|c|}{ Nutrient Content of Dry Matter (DM) } & \multicolumn{2}{|c|}{ Analysis Results } \\
\hline \multicolumn{2}{|c|}{ Dry Matter \% } & \multicolumn{2}{|c|}{94.20} \\
\hline \multicolumn{2}{|l|}{ Crude Ash \% } & \multicolumn{2}{|c|}{6.38} \\
\hline \multicolumn{2}{|l|}{ Crude Fat $\%$} & 8.2 & \\
\hline Crude Protein $\%$ & & 10 . & \\
\hline Crude Cellulose \% & & 32. & \\
\hline $\mathrm{Ca} \%$ & & 0.8 & \\
\hline $\mathrm{P} \%$ & & 0. & \\
\hline Sugar \% & & 0. & \\
\hline Metabolic Energy kcal/kg & & 25 & \\
\hline
\end{tabular}

Table 3. The body weight values of the quails in each study group (g)

\begin{tabular}{|c|c|c|c|c|c|c|}
\hline \multirow{2}{*}{ Week } & \multicolumn{4}{|c|}{ Groups } & \multirow{2}{*}{ SEM } & \multirow{2}{*}{$\mathrm{P}$} \\
\hline & Control & Group I & Group II & Group III & & \\
\hline Initial Weight & 8.96 & 9.02 & 8.99 & 8.90 & 0.038 & 0.701 \\
\hline Week 1 & $21.07^{\mathrm{a}}$ & $20.09^{a}$ & $20.19^{a}$ & $18.62^{\mathrm{b}}$ & 0.182 & 0.000 \\
\hline Week 2 & $41.61^{\mathrm{a}}$ & $38.85^{\mathrm{b}}$ & $40.21^{\mathrm{ab}}$ & $36.62^{c}$ & 0.393 & 0.000 \\
\hline Week 3 & $77.77^{\mathrm{a}}$ & $74.12^{\mathrm{b}}$ & $75.61^{\mathrm{ab}}$ & $68.35^{\mathrm{c}}$ & 0.591 & 0.000 \\
\hline Week 4 & $117.49^{\mathrm{a}}$ & $114.02^{\mathrm{a}}$ & $116.90^{\mathrm{a}}$ & $110.01^{\mathrm{b}}$ & 0.733 & 0.002 \\
\hline Week 5 & $156.77^{\mathrm{a}}$ & $152.01^{b}$ & $156.87^{\mathrm{a}}$ & $148.03^{b}$ & 0.809 & 0.000 \\
\hline Week 6 & 188.15 & 183.94 & 186.66 & 182.45 & 1.309 & 0.405 \\
\hline
\end{tabular}

a,b,c: Differences between means with different superscripts in the same row are significant $(\mathrm{P}<0.05)$.

\section{Result and Discussion}

The mean body weights determined throughout the study period for the study groups, which were given different levels of dietary olive cake meal, are presented in Table 3. While no statistically significant difference was observed between the groups for the mean initial weights, the mean body weights determined until the $6^{\text {th }}$ week of the study differed significantly $(\mathrm{P}<0.01, \mathrm{P}<0.001)$. The differences detected between the control group and Group III were particularly significant $(\mathrm{P}<0.001, \mathrm{P}<0.01)$.
The body weight and body weight gain values of the male and female quails in each group are presented in Table 4. When compared for mean body weight, the differences observed in weeks 3 and 5 between the male and female quails of the control group and Group III, and in week 4 between the male quails in Group III and the quails in the other groups were statistically significant $(\mathrm{P}<0.001 ; \mathrm{P}<0.01)$. In week 6 , the male and female quails of the four study groups showed no difference for mean body weight. It was ascertained that the body weight gain 
of the male quails between weeks 3-6 was significantly lower in the control group, when compared to Groups II and III $(\mathrm{P}<0.001)$.

The body weight gain, feed intake and feed conversion rate values of the study groups for the selected time periods are presented in Table 5. The study groups did not differ for body weight gain and feed intake $(\mathrm{P}>0.05)$. On the other hand, the feed conversion rates of the groups differed and body weight gain between weeks 0-3, and the control group showed significant differences in comparison to Groups I III and Groups III, respectively $(\mathrm{P}<0.05)$.

\section{Slaughter and Carcass Traits}

The slaughter traits determined for the study groups at the end of the fattening period are presented in Table 6 . The study groups differed for the mean values determined for eviscerated hot carcass weight $(\mathrm{P}<0.01)$, heart weight $(\mathrm{P}<0.001)$, gizzard weight $(\mathrm{P}<0.05)$, and heart and gizzard percentages $(\mathrm{P}<0.01)$.

The comparison of the female quails in the study groups for slaughter traits revealed that no difference existed, except for the gizzard percentage $(\mathrm{P}<0.05)$ (Table 7). On the other hand, male quails significantly differed for body weight at slaughter $(\mathrm{P}<0.05)$, eviscerated hot carcass weight $(\mathrm{P}<0.01)$, heart weight $(\mathrm{P}<0.001)$, gizzard weight $(\mathrm{P}<0.05)$ and heart percentage $(\mathrm{P}<0.01)$.

The comparison of the study groups for the weights and percentages of the carcass parts demonstrated that, excluding those detected for the breast percentage, all differences were statistically significant $(\mathrm{P}<0.05, \mathrm{P}<0.01$, $\mathrm{P}<0.001$ ) (Table 8).

While the female quails were determined to show statistically significant differences for wing weight, thigh weight $(\mathrm{P}<0.01)$ and thigh percentage $(\mathrm{P}<0.05)$, the male quails significantly differed for all carcass traits, excluding the thigh percentage $(\mathrm{P}<0.05, \mathrm{P}<0.01, \mathrm{P}<0.001)$ (Table 9)
Group III, which received $7.5 \%$ of dietary OCM, displayed lower mean body weight values during the first 5 weeks of the study, when compared to the control group and the other two treatment groups $(2.5 \%$ and $5 \%$ of dietary OCM) (Table 3). In view of the crude cellulose content of OCM (32.40\%) (Table 3), the body weight values of the quails in Group III, which were fed on a higher level of crude cellulose, being lower was considered normal. Similarly, in their study on the dietary supplementation of broiler chickens with different levels of olive pulp $(0 \%, 2.5 \%, 5 \%, 7.5 \%$ and $10 \%)$, Rabayaa et al. (2001) reported that the body weight values of the chickens that received $10 \%$ of olive pulp were significantly lower throughout the 35 day-fattening period. However, in the present study, the groups did not show any statistically significant difference in week 6 . It is known that the digestive tract of poultry species is short with respect to their body size, thus, their digestive capacity is limited and characterized by weak cellulose activity. Therefore, feed containing low amounts of cellulose are preferred to be used in poultry nutrition. However, in the present study, despite its high crude cellulose content (32.40\%), olive cake meal did not cause any statistically significant difference for body weight between the control and treatment groups throughout the study period. This result agrees with several literature reports. Dietary supplementation with olive cake and olive mill wastes has been reported to cause statistically insignificant differences for mean body weight values in broiler chickens (AlHarthi, 2016; El Hachemi et al., 2007). Similarly, in nutritional research conducted on various olive industry by-products, growth parameters have been reported not to be affected (Shafey et al., 2013). Differently, Hadi and AlKhalisy (2018) reported that the mean weekly body weight values of broiler chickens increased directly proportional to the level of dietary olive oil supplementation.

Table 4. The weekly body weight and body weight gain values of the male and female quails in each study group (g)

\begin{tabular}{|c|c|c|c|c|}
\hline \multirow{2}{*}{ Groups } & \multicolumn{4}{|c|}{ Weeks } \\
\hline & Week 3 & Week 4 & Week 5 & Week 6 \\
\hline Control F & $76.67^{\mathrm{ab}}$ & $116.83^{a}$ & $159.01^{\mathrm{a}}$ & $200.36^{\mathrm{a}}$ \\
\hline Control M & $79.67^{a}$ & $118.63^{\mathrm{a}}$ & $152.91^{\mathrm{abc}}$ & $167.11^{b}$ \\
\hline Group I F & $72.53^{\mathrm{bc}}$ & $114.04^{\mathrm{a}}$ & $157.32^{\mathrm{a}}$ & $198.10^{\mathrm{a}}$ \\
\hline Group I M & $75.58^{\mathrm{abc}}$ & $114.01^{\mathrm{a}}$ & $147.14^{\mathrm{cd}}$ & $170.94^{\mathrm{b}}$ \\
\hline Group II F & $74.55^{\mathrm{abc}}$ & $115.14^{\mathrm{a}}$ & $157.63^{\mathrm{a}}$ & $194.78^{a}$ \\
\hline Group II M & $77.38^{\mathrm{ab}}$ & $117.08^{\mathrm{a}}$ & $155.91^{\mathrm{ab}}$ & $176.27^{b}$ \\
\hline Group III F & $70.81^{\mathrm{c}}$ & $112.69^{\mathrm{ab}}$ & $149.91^{\mathrm{bcd}}$ & $192.91^{\mathrm{a}}$ \\
\hline Group III M & $65.56^{\mathrm{d}}$ & $106.99^{b}$ & $145.90^{\mathrm{d}}$ & $170.63^{b}$ \\
\hline SEM & 0.597 & 0.744 & 0.807 & 1.156 \\
\hline $\mathrm{P}$ & 0.000 & 0.009 & 0.000 & 0.000 \\
\hline Groups & Weeks 3-4 & Weeks 4-5 & Weeks 5-6 & Weeks 3-6 \\
\hline Control F & 40.16 & $42.18^{\mathrm{ab}}$ & $41.36^{\mathrm{a}}$ & $123.69^{\mathrm{a}}$ \\
\hline Control M & 38.96 & $34.28^{\mathrm{bc}}$ & $15.55^{\mathrm{b}}$ & $87.44^{\mathrm{c}}$ \\
\hline Group I F & 41.51 & $43.28^{\mathrm{a}}$ & $40.78^{a}$ & $125.57^{\mathrm{a}}$ \\
\hline Group I M & 38.43 & $33.13^{c}$ & $23.81^{\mathrm{b}}$ & $95.36^{\mathrm{bc}}$ \\
\hline Group II F & 40.57 & $41.89^{\mathrm{ab}}$ & $39.70^{\mathrm{a}}$ & $121.20^{\mathrm{a}}$ \\
\hline Group II M & 42.49 & $36.24^{\mathrm{abc}}$ & $23.25^{\mathrm{b}}$ & $98.23^{b}$ \\
\hline Group III F & 41.88 & $36.67^{\mathrm{abc}}$ & $42.90^{\mathrm{a}}$ & $121.98^{\mathrm{a}}$ \\
\hline Group III M & 41.42 & $39.31^{\mathrm{abc}}$ & $24.74^{\mathrm{b}}$ & $104.90^{\mathrm{b}}$ \\
\hline SEM & 0.822 & 0.038 & 1.110 & 1.286 \\
\hline $\mathrm{P}$ & 0.929 & 0.943 & 0.000 & 0.000 \\
\hline
\end{tabular}


Table 5. The body weight, feed intake and feed conversion rate values of the quails in each study group

\begin{tabular}{l|cccccc}
\hline \multirow{2}{*}{ Weeks } & \multicolumn{7}{c}{ Groups } \\
\cline { 2 - 7 } & Control & Group I & Group II & Group III & SEM & P \\
\hline \multicolumn{7}{c}{ Mean body weight gain, g } \\
\hline Weeks 0-3 & $22.94^{\mathrm{a}}$ & $21.76^{\mathrm{a}}$ & $22.23^{\mathrm{a}}$ & $19.81^{\mathrm{b}}$ & 0.263 & 0.004 \\
Weeks 3-6 & 36.87 & 36.25 & 36.92 & 37.93 & 1.033 & 0.951 \\
Weeks 0-6 & 29.91 & 29.01 & 29.57 & 28.87 & 0.475 & 0.851 \\
\hline \multicolumn{7}{c}{ Mean feed intake, g/week } \\
\hline Weeks 0-3 & 57.70 & 59.92 & 60.51 & 57.61 & 0.740 & 0.408 \\
Weeks 3-6 & 168.95 & 166.29 & 177.89 & 167.61 & 1.740 & 0.119 \\
Weeks 0-6 & 113.33 & 113.11 & 119.20 & 112.61 & 0.970 & 0.091 \\
\hline \multicolumn{7}{c}{ Feed conversion rate, g/g } \\
\hline Weeks 0-3 & $2.52^{\mathrm{b}}$ & $2.75^{\mathrm{a}}$ & $2.72 \mathrm{ab}$ & $2.91^{\mathrm{a}}$ & 0.038 \\
Weeks 3-6 & 4.70 & 4.64 & 4.86 & 4.44 & 0.153 & 0.016 \\
Weeks 0-6 & 3.82 & 3.91 & 4.04 & 3.91 & 0.078 \\
\hline
\end{tabular}

a,b: Differences between means with different superscripts in the same row are significant $(\mathrm{P}<0.05)$.

Table 6. Slaughter traits of the quails in each study group

\begin{tabular}{|c|c|c|c|c|c|c|}
\hline \multirow{2}{*}{ Traits } & \multicolumn{4}{|c|}{ Groups } & \multirow[b]{2}{*}{ SEM } & \multirow[b]{2}{*}{$\mathrm{P}$} \\
\hline & Control & Group I & Group II & Group III & & \\
\hline Live weight at slaughter (g) & $182.57 \pm 3.03$ & $184.42 \pm 2.51$ & $186.00 \pm 2.32$ & $181.76 \pm 2.74$ & 1.331 & 0.678 \\
\hline Eviscerated hot carcass weight (g) & $122.76 \pm 1.75^{b}$ & $130.56 \pm 1.35^{\mathrm{a}}$ & $128.92 \pm 1.53^{\mathrm{a}}$ & $123.45 \pm 1.61^{\mathrm{b}}$ & 0.783 & 0.001 \\
\hline Heart weight $(\mathrm{g})$ & $1.65 \pm 0.03^{\mathrm{bc}}$ & $1.75 \pm 0.03^{\mathrm{ab}}$ & $1.84 \pm 0.08^{\mathrm{a}}$ & $1.56 \pm 0.04^{\mathrm{c}}$ & 0.024 & 0.000 \\
\hline Liver weight (g) & $4.02 \pm 0.19$ & $4.14 \pm 0.20$ & $4.29 \pm 0.19$ & $4.26 \pm 0.19$ & 0.098 & 0.752 \\
\hline Gizzard weight (g) & $3.37 \pm 0.10^{\mathrm{b}}$ & $3.37 \pm 0.08^{b}$ & $3.60 \pm 0.10^{\mathrm{ab}}$ & $3.72 \pm 0.10^{\mathrm{a}}$ & 0.048 & 0.025 \\
\hline Heart percentage $(\%)$ & $0.91 \pm 0.02^{\mathrm{bc}}$ & $0.96 \pm 0.02^{\mathrm{ab}}$ & $0.99 \pm 0.04^{\mathrm{a}}$ & $0.86 \pm 0.02^{\mathrm{c}}$ & 0.012 & 0.002 \\
\hline Liver percentage $(\%)$ & $2.18 \pm 0.08$ & $2.22 \pm 0.09$ & $2.30 \pm 0.09$ & $2.32 \pm 0.08$ & 0.038 & 0.628 \\
\hline Gizzard percentage $(\%)$ & $1.85 \pm 0.04^{\mathrm{b}}$ & $1.83 \pm 0.04^{\mathrm{b}}$ & $1.94 \pm 0.05^{\mathrm{ab}}$ & $2.05 \pm 0.05^{\mathrm{a}}$ & 0.022 & 0.003 \\
\hline
\end{tabular}

a,b,c: Differences between means with different superscripts in the same row are significant $(\mathrm{P}<0.05)$.

Table 7. Mean slaughter trait values of the study groups with respect to sex

\begin{tabular}{|c|c|c|c|c|c|c|c|}
\hline \multirow{2}{*}{\multicolumn{2}{|c|}{ Traits }} & \multicolumn{4}{|c|}{ Groups } & \multirow{3}{*}{$\begin{array}{l}\text { SEM } \\
0.927\end{array}$} & \\
\hline & & \multirow{2}{*}{$\begin{array}{c}\text { Control } \\
199.28\end{array}$} & \multirow{2}{*}{$\begin{array}{c}\text { Group I } \\
198.24\end{array}$} & \multirow{2}{*}{$\begin{array}{c}\text { Group II } \\
196.75\end{array}$} & \multirow{2}{*}{$\begin{array}{c}\text { Group III } \\
194.47\end{array}$} & & \\
\hline \multirow{8}{*}{ Female } & Body weight at slaughter (g) & & & & & & 0.300 \\
\hline & Eviscerated hot carcass weight $(\mathrm{g})$ & 127.40 & 133.20 & 129.94 & 125.09 & 1.144 & 0.085 \\
\hline & Heart weight $(\mathrm{g})$ & 1.69 & 1.82 & 1.94 & 1.66 & 0.042 & 0.077 \\
\hline & Liver weight $(\mathrm{g})$ & 4.84 & 5.14 & 4.94 & 5.02 & 0.119 & 0.836 \\
\hline & Gizzard weight (g) & 3.75 & 3.70 & 3.89 & 4.08 & 0.062 & 0.146 \\
\hline & Heart percentage $(\%)$ & 0.85 & 0.92 & 0.99 & 0.85 & 0.021 & 0.072 \\
\hline & Liver percentage $(\%)$ & 2.42 & 2.59 & 2.52 & 2.58 & 0.059 & 0.719 \\
\hline & Gizzard percentage $(\%)$ & $1.88^{\mathrm{b}}$ & $1.87^{\mathrm{b}}$ & $1.98^{\mathrm{ab}}$ & $2.10^{\mathrm{a}}$ & 0.032 & 0.053 \\
\hline \multirow{8}{*}{ Male } & Live weight at slaughter & $165.86^{\mathrm{b}}$ & $170.59^{\mathrm{ab}}$ & $175.25^{\mathrm{a}}$ & $168.33^{\mathrm{b}}$ & 1.153 & 0.033 \\
\hline & Eviscerated hot carcass weight (g) & $118.12^{\mathrm{b}}$ & $127.91^{\mathrm{a}}$ & $127.90^{\mathrm{ab}}$ & $121.71^{b}$ & 0.992 & 0.001 \\
\hline & Heart weight $(\mathrm{g})$ & $1.62^{\mathrm{b}}$ & $1.69^{\mathrm{ab}}$ & $1.75^{\mathrm{a}}$ & $1.46^{\mathrm{c}}$ & 0.021 & 0.000 \\
\hline & Liver weight $(\mathrm{g})$ & 3.20 & 3.14 & 3.64 & 3.44 & 0.080 & 0.111 \\
\hline & Gizzard weight (g) & $3.00^{\mathrm{c}}$ & $3.04^{\mathrm{bc}}$ & $3.31^{\mathrm{ab}}$ & $3.34^{\mathrm{a}}$ & 0.050 & 0.028 \\
\hline & Heart percentage $(\%)$ & $0.98^{\mathrm{a}}$ & $0.99^{\mathrm{a}}$ & $1.00^{\mathrm{a}}$ & $0.87^{\mathrm{b}}$ & 0.013 & 0.002 \\
\hline & Liver percentage $(\%)$ & 1.93 & 1.85 & 2.07 & 2.05 & 0.046 & 0.275 \\
\hline & Gizzard percentage (\%) & 1.81 & 1.79 & 1.90 & 1.99 & 0.031 & 0.105 \\
\hline
\end{tabular}

a,b,c: Differences between means with different superscripts in the same row are significant $(\mathrm{P}<0.05)$.

Table 8 . Traits of the carcass parts in the study groups

\begin{tabular}{|c|c|c|c|c|c|c|}
\hline \multirow{2}{*}{ Traits } & \multicolumn{4}{|c|}{ Groups } & \multirow{2}{*}{ SEM } & \multirow{2}{*}{$\mathrm{P}$} \\
\hline & Control & Group I & Group II & Group III & & \\
\hline Eviscerated cold carcass weight & $122.41^{\mathrm{c}}$ & $129.91^{\mathrm{a}}$ & $128.36^{\mathrm{ab}}$ & $124.35^{\mathrm{bc}}$ & 0.894 & 0.012 \\
\hline Wing weight & $8.35^{\mathrm{b}}$ & $9.78^{\mathrm{a}}$ & $10.21^{\mathrm{a}}$ & $9.87^{\mathrm{a}}$ & 0.121 & 0.000 \\
\hline Breast weight & $37.22^{\mathrm{b}}$ & $40.20^{\mathrm{a}}$ & $41.46^{\mathrm{a}}$ & $39.13^{\mathrm{ab}}$ & 0.412 & 0.003 \\
\hline Back + neck weight & $50.49^{\mathrm{a}}$ & $50.80^{\mathrm{a}}$ & $48.00^{\mathrm{ab}}$ & $46.30^{\mathrm{b}}$ & 0.527 & 0.008 \\
\hline Thigh weight & $25.60^{\mathrm{b}}$ & $28.54^{\mathrm{a}}$ & $28.28^{\mathrm{a}}$ & $26.72^{\mathrm{b}}$ & 0.203 & 0.000 \\
\hline Wing percentage & $6.82^{\mathrm{b}}$ & $7.54^{\mathrm{a}}$ & $8.00^{\mathrm{a}}$ & $7.99^{\mathrm{a}}$ & 0.098 & 0.000 \\
\hline Breast percentage & 30.47 & 30.99 & 32.28 & 31.80 & 0.315 & 0.179 \\
\hline Back + neck percentage & $41.19^{\mathrm{a}}$ & $39.07^{\mathrm{b}}$ & $37.43^{\mathrm{b}}$ & $37.30^{\mathrm{b}}$ & 0.328 & 0.000 \\
\hline Thigh percentage & $20.91^{\mathrm{b}}$ & $21.98^{\mathrm{a}}$ & $22.06^{\mathrm{a}}$ & $21.60^{\mathrm{a}}$ & 0.118 & 0.002 \\
\hline
\end{tabular}


Table 9. Carcass part traits of the study groups with respect to sex

\begin{tabular}{c|l|cccccc}
\hline \multicolumn{1}{c}{ Traits } & Control & Group I & Group II & Group III & SEM & P \\
\hline \multirow{5}{*}{ Fex } & Eviscerated cold carcass weight & 126.64 & 132.73 & 130.15 & 126.87 & 1.467 & 0.408 \\
& Wing weight & $8.61^{\mathrm{bc}}$ & $9.70^{\mathrm{a}}$ & $9.38^{\mathrm{ab}}$ & $8.36^{\mathrm{c}}$ & 0.144 & 0.004 \\
& Breast weight & 39.90 & 41.29 & 41.24 & 40.24 & 0.608 & 0.801 \\
& Back + neck weight & 50.96 & 51.84 & 50.09 & 47.97 & 0.757 & 0.317 \\
& Thigh weight & $26.26^{\mathrm{b}}$ & $29.28^{\mathrm{a}}$ & $28.74^{\mathrm{a}}$ & $26.83^{\mathrm{b}}$ & 0.308 & 0.002 \\
& Wing percentage & $6.82^{\mathrm{a}}$ & 7.31 & 7.26 & $6.62^{\mathrm{b}}$ & 0.108 & 0.077 \\
& Breast percentage & 31.58 & 31.17 & 31.62 & 32.40 & 0.499 & 0.850 \\
& Back + neck percentage & 40.17 & 39.04 & 38.65 & 38.03 & 0.495 & 0.483 \\
& Thigh percentage & $20.73^{\mathrm{b}}$ & $22.05^{\mathrm{a}}$ & $22.12^{\mathrm{a}}$ & $21.33^{\mathrm{ab}}$ & 0.187 & 0.029 \\
\hline \multirow{5}{*}{ Male } & Eviscerated cold carcass weight & $118.17^{\mathrm{b}}$ & $127.09^{\mathrm{a}}$ & $126.58^{\mathrm{a}}$ & $121.83^{\mathrm{ab}}$ & 0.949 & 0.003 \\
& Wing weight & $8.09^{\mathrm{c}}$ & $9.85^{\mathrm{b}}$ & $11.05^{\mathrm{a}}$ & $11.37^{\mathrm{a}}$ & 0.140 & 0.000 \\
& Breast weight & $34.54^{\mathrm{c}}$ & $39.11^{\mathrm{ab}}$ & $41.69^{\mathrm{a}}$ & $38.02^{\mathrm{b}}$ & 0.514 & 0.000 \\
& Back + neck weight & $50.02^{\mathrm{a}}$ & $49.76^{\mathrm{a}}$ & $45.92^{\mathrm{ab}}$ & $44.63^{\mathrm{b}}$ & 0.716 & 0.017 \\
& Thigh weight & $24.94^{\mathrm{b}}$ & $27.80^{\mathrm{a}}$ & $27.82^{\mathrm{a}}$ & $26.60^{\mathrm{a}}$ & 0.256 & 0.000 \\
& Wing percentage & $6.83^{\mathrm{c}}$ & $7.76^{\mathrm{b}}$ & $8.75^{\mathrm{a}}$ & $9.35^{\mathrm{a}}$ & 0.107 & 0.000 \\
& Breast percentage & $29.37^{\mathrm{b}}$ & $30.81^{\mathrm{ab}}$ & $32.94^{\mathrm{a}}$ & $31.20^{\mathrm{ab}}$ & 0.379 & 0.014 \\
& Back + neck percentage & $42.22^{\mathrm{a}}$ & $39.10^{\mathrm{b}}$ & $36.21^{\mathrm{c}}$ & $36.58^{\mathrm{c}}$ & 0.422 & 0.000 \\
& Thigh percentage & 21.08 & 21.88 & 22.00 & 21.86 & 0.146 & 0.112 \\
\hline
\end{tabular}

a,b,c: Differences between means with different superscripts in the same row are significant $(\mathrm{P}<0.05, \mathrm{P}<0.01, \mathrm{P}<0.001)$.

The comparison of the study groups for sex revealed that, throughout the study period, the mean body weight values of the male and female quails in Group III were lower than those of the quails in the control group and the two other treatment groups (Table 4). Similarly, in a recent study, it has been reported that body weight gain was lowest in the group that was fed on the highest amount of olive pulp (Papadomichelakis et al., 2019).

No adverse effect was determined for dietary olive cake meal supplementation on the feed intake of quails between weeks 0-6 (Table 5). In this respect, although olive cake meal has been suggested to be more favourable for ruminants due to its high crude cellulose content (Amici et al., 1991; Weinberg et al., 2008; Ghasemi et al., 2014), the results of the present study have shown that OCM has no negative impact on poultry nutrition. Although the feed conversion rate was determined to have decreased with dietary OCM supplementation between weeks 0-3, no such effect was observed in the late periods of the study (weeks 3-6, weeks 0-6). The decrease detected in the feed conversion rate in association with dietary OCM supplementation between weeks 0-3 could be attributed to the acclimatisation of the birds to OCM. Indeed, in the following weeks, no negative effect was observed on body weight, feed intake and feed conversion rate. In this respect, the results of the present study are in agreement with those reported in some previously conducted research (Rabayaa et al., 2001; Ozdemir and Azman, 2013; Zhang et al., 2013; Cayan and Erener, 2015; Tuzun and Unlu, 2016). On the other hand, some studies suggest that olive mill wastes do not affect feed intake, but improve the feed conversion rate (Shafey et al., 2013; Al-Harthi, 2016; Sateri et al., 2017; Amini et al., 2019; Erener et al., 2020).

Groups I and II, which had quantitatively higher slaughter body weights that were of no statistical significance, displayed significantly higher eviscerated hot carcass weights in comparison to the control group and Group III (Table 6). The heart weight and percentage were highest in Group II and significantly differed from the values determined in the control group and Group III. The gizzard weight and percentage were highest in Group III and significantly differed from the values detected in the control group and Group I. Similar to the present study, a previous study conducted by Al-Harthi (2016) demonstrated that dietary olive pulp increased the heart percentage, when supplemented at a level of $5 \%$, and increased the gizzard percentage, when supplemented at a level of $10 \%$. In another study carried out by Al-Harthi and Attia (2016) on different levels of dietary olive pulp supplementation $(0 \%, 10 \%$, $20 \%$ ), it was ascertained that $10 \%$ of the supplement increased the heart percentage and $20 \%$ of the supplement increased the gizzard percentage, when compared to the other groups. As is the case in the present study, it can be said that the level of olive pulp incorporated in the diet was correlated with the increase observed in the gizzard percentage in the studies previously conducted by Al-Harthi (2016) and Al-Harthi and Attia (2016). Thus, it is considered that an increase in the amount of relatively less digestible nutrients in the composition of feed (basal diet) induces the physical activity of the gizzard, which eventually reflects on the weight of this organ.

The comparison of the female quails in the study groups for slaughter traits showed that, differences existed only for the gizzard percentage with the values being higher in Group III, compared to the control group and Group I (Table 7). With respect to the traits of the carcass parts, it was observed that wing weight was higher in Group I, and thigh weight and percentage were higher in Groups I and II, when compared to the other groups (Table 9). In the male quails, all slaughter traits, excluding liver weight, liver percentage were observed to have been affected by dietary OCM supplementation, and the most favourable slaughter traits were determined in Group II (Table 7). As regards the traits of the carcass parts, excluding the back+neck weight and percentage, all traits were determined to have increased with dietary OCM supplementation (Table 9).

In comparison to the control group, eviscerated cold carcass weight, breast weight and thigh weight were determined to be higher in Groups I and II. Wing weight, wing percentage and thigh percentage were higher in all treatment groups, compared to the controls. The back+neck 
weight was lowest in Group III (Table 8). Based on these results, it is suggested that dietary supplementation with OCM, in particular at a level of $5 \%$, positively affects the highly consumed breast, thighs and wings. Indeed, it has been reported that dietary supplementation with various olive industry by-products (olive leaf, olive cake) positively affects breast, thigh and wing weights in broiler chickens (Shafey et al., 2013, Sateri et al., 2017). It has also been reported that dietary olive leaf extract does not have any effect on breast percentage and thigh percentage in broiler chickens (Sarıca and Ürkmez, 2016).

\section{Conclusion}

In conclusion, in view of the high feed costs challenging the poultry sector, it is significant that dietary supplementation with olive cake meal, particularly at a level of $5 \%$, yields body weight values closest to those achieved with a standard basal diet, and shows no adverse effect on other performance parameters. Thus, the use of olive cake meal, an olive industry by-product, as an alternative feedstuff rather than a feed supplement in poultry nutrition would not only reduce feed costs, but also contribute to reducing environmental pollution.

\section{References}

Al-Harthi MA. 2016. The efficacy of using olive cake as a byproduct in broiler feeding with or without yeast. Italian Journal of Animal Science, 15(3): 512-520.

Al-Harthi MA, Attia YA. 2016. Effect of citric acid on the utilization of olive cake diets by laying hens. Italian Journal of Animal Science, 14(3):394-402.

Amici A, Verna,M, Martillotti F. 1991. Olive byproducts in animal feeding: improvement and utilization. Options Méditerranéennes-Series Seminaries, 16: 149-152.

Amini A, Parsaei S, Houshmand M, Naghiha R. 2019. Effect of olive leaf powder on the performance and ileal bacterial count of broilers. Veterinary Research Forum,10(3): 255-259.

AOAC, 1990. Official Methods of Analysis of the Association of Official Analytical Chemists, Vol. II, 15th ed. Sec.985.29. The Association: Arlington, VA.

Cayan H, Erener G. 2015. Effect of olive leaf (olea europaea) powder on laying hens' performance, egg quality and egg yolk cholesterol levels. Asian Australas. J. Anim. Sci. 28(4): 538-543.

Chiofalo B, Liotta L, Zumbo A, Chiofalo V. 2004. Administration of olive cake for ewe feeding: effect on milk yield and composition. Small Ruminant Research, 55: 169-176.

Cibik M, Keles G. 2016. Effect of stoned olive cake on milk yield and composition of dairy cows", Revue de Médecine Vétérinaire, 167(5-6): 154-158.

Crampton EW, Maynard LA. 1983. The relation of cellulose and lignin content to the nutritive value of animal feeds. J. Nut, 15: 383-395.

Dalkilic B. 2018. Zeytinyağı Endüstrisi Yan Ürünlerinin Hayvan Besleme Alanında Değerlendirilme Olanakları. El-Cezerî Fen ve Mühendislik Dergisi, 5(3): 917-926.

El-Hachemi A, El-Mecherfi KE, Benzineb K, Saidi D, Kheroua O. 2007. Supplementation of olive mill wastes in broiler chicken feeding. African Journal of Biotechnology, 6(15): 1848-1853.

Erener G, Ocak N, Ozturk E, Cankaya S, Ozkanca R, Altop A. 2020. Evaluation of olive leaf extract as a growth promoter on the performance, blood biochemical parameters, and caecal microflora of broiler chickens. R. Bras. Zootec., 49: e20180300.
Ghasemi R, Torki M, Ghasemi HA, Zarei M. 2014. Single or combined effects of date pits and olive pulps on productive traits, egg quality, serum lipids and leucocytes profiles of laying hens. Journal of Applied Animal Research, 42(1): 103-109.

Hadi DS, Al-khalisy AF. 2018. The effect of different levels of olive oil in ration supplementation on some biochemical and productive traits in broilers. IJSN, 9(1): 137-142.

Ibrahim NS, Sabic EM, Abu-Taleb AM. 2018. Effect of inclusion irradiated olive pulp in laying quail diets on biological performance. Journal of Radiation Research and Applied Sciences, 11: 340-346.

Larbier M, Leclercq B. 1994."Nutrition and feeding of poultry". Edited. Julian Wiseman. Nottingham University Press (1994).

NRC, 1994. National Research Council, Nutrient Requirements of Poultry. 9th rev. ed. National Academy Press, Washington, DC.

Ozdemir A, Azman MA. 2013. The effects of supplemental olive leaf extract in diet on performance of quails. Firat Univ Vet $\mathbf{J}$ Health Sci, 27: 141-147.

Ozdogan M, Ustundag AO, Yarali E. 2017. Effect of mixed feeds containing different levels of olive cake on fattening performance, carcass, meat quality and fatty acids of lambs. Tropical Animal Health and Production, 49: 1631-1636.

Papadomichelakis G, Pappas AC, Tsiplakou E, Symeon GK, Sotirakoglou K, Mpekelis V, Fegeros K, Zervas G. 2019. Effects of dietary dried olive pulp inclusion on growth performance and meat quality of broiler chickens. Livest. Sci., 221: 115-122.

Rabayaa E, Abo Omar JM, Othman RA. 2001. Utilization of olive pulp in broiler rations. An-Najah Univ. J. Res., 15: 133-144.

Sadeghi H, Yansari AT, Ansari-Pirsarai Z. 2009. Effects of different olive cake by products on dry matter intake, nutrient digestibility and performance of Zel sheep, International Journal of Agriculture Biology, 11: 39-43.

Sarica S, Urkmez D. 2018. Comparison of the effects of dietary supplementation of natural antimicrobial feed additives on lipid oxidation, microbial content and quality of broiler raw meat. Turkish Journal of Agriculture - Food Science and Technology, 6(11): 1537-1543.

Sateri S, Seidavi A, Bouyeh M, Neumann P, Kutzler M, Laudadio V, Loperfido F, Tufarelli V. 2017. Effect of olive meal and supplemental enzymes on performance traits, blood biochemistry, humoral immunity response and caecal microbiota of broilers. South African Journal of Animal Science, 47(6): 804-812.

Shafey TM, Almufarij SI, Albatshan HA. 2013. Effect of feeding olive leaves on the performance, intestinal and carcass characteristics of broiler chickens. Int. J. Agric. Biol., 13(3): 585-589.

Tuzun AE, Unlu HB. 2016. Farklı düzeylerde zeytin pulpu ilave edilmiş karmalarla yemlenen etlik piliçlerin besi performansı ve but eti yağ asitleri kompozisyon. Hayvansal Üretim, 57(2): $15-21$.

Weinberg ZG, Chen Y, Weinberg P. 2008. Ensiling olive cake with and without molasses for ruminant feeding. Bioresource Technology, 99: 1526-1529.

Zangeneh S, Torki M. 2011. Effects of B-mannanase supplementing of olive pulp-1ncluded diet on performance of laying hens, egg quality characteristics, humoral and cellular 1mmune response and blood parameter. Global Veterinaria, 7(4): 391-398.

Zarei M, Ehsani M, Torki M. 2011. Productive performance of laying hens fed wheat-based diets included olive pulp with or without a commercial enzyme product. African Journal of Biotechnology, 10(20): 4303-4312.

Zhang ZF, Zhou TX, Kim IH. 2013. Effects of dietary olive oil on growth performance, carcass parameters, serum characteristics, and fatty acid composition of breast and drumstick meat in broilers. Asian-Aust. J. Anim. Sci., 26(3): 416-422. 